УДК 342.922

DOI https://doi.org/10.51989/NUL.2021.4.19

\title{
ПРАВОВА ХАРАКТЕРИСТИКА ПАРИЗЬКОЇ УГОДИ ЯК ОСНОВИ ФОРМУВАННЯ НАЦІОНАЛЬНОЇ ПОЛІТИКИ ПРОТИДІї ЗМІНАМ КЛІМАТУ (КЛІМАТИЧНОÏ ПОЛІТИКИ)
}

\author{
Сушик Ольга Володимирівна, \\ кандидат юридичних наук, \\ докторантка кафедри службового та медичного права, \\ заступник директора Центру європейських студій \\ Інституту права \\ Київського національного університету імені Тараса Шевченка
}

Статтю присвячено науково-правовому аналізу Паризької угоди в межах Рамкової конвенції ООН про зміну клімату як базису для формування та реалізації національної політики протидії змінам клімату. Встановлено, що вже у преамбулі містяться положення щодо захисту порушених прав людини, пов'язаних зі зміною клімату в суді, зокрема права майбутніх поколінь, корінних народів, мігрантів, розширення можливостей для жінок та інші.

У статті визначено, що для реалізації головної мети Паризької угоди (стримування зростання глобальної середньої температури значно нижче $\left.2{ }^{\circ} \mathrm{C}\right)$ сторони мають якомога швидше досягти глобального піку викидів парникових газів, беручи до уваги, що досягнення такого піку потребує більш тривалого часу для сторін - країн, що розвиваються, та досягнути балансу між антропогенними викидами із джерел та абсорбцією поглиначами парникових газів у другій половині цього століття (кліматична нейтральність). Відповідно до Паризької угоди основою для досягнення кліматичної нейтральності $\epsilon$ багатофункціональне і стале управління лісами.

Встановлено, що Паризька угода базується на специфічному правовому механізмі - національно визначених внесках країн-учасниць (HBВ) щодо зменшення викидів парникових газів та пом'якшення наслідків змін клімату на національному рівні. Від кожної сторони вимагається: розробити, повідомити та підтримувати НВВ, який вона має намір досягти (кожні 5 років), що буде відображати ії найбільш можливі амбіції, ніж попередній нвВ; надавати у НВВ інформацію, необхідну для забезпечення ясності, прозорості та розуміння; здійснювати облік антропогенних викидів відповідно до їхніх НBВ, ураховуючи екологічну цілісність; надавати регулярну інформацію в національній доповіді про національний кадастр антропогенних викидів із джерел та абсорбції поглиначами парникових газів. Таким чином, держави зобов'язуються застосувати у своїх національних політиках протидії змінам клімату (кліматичних політиках) ті заходи (в т.ч. правового характеру), які будуть спрямовані на досягнення цілей, що містяться в їхніх НВВ.

у статті також визначається, що Паризька угода запровадила нову модель «гібридного мультилатералізму», що передбачає важливу роль національних недержавних суб'єктів щодо протидії змінам клімату (територіальні громади, підприємства, громадські організації і більш широко - громадянське суспільство).

Ключові слова: зміни клімату, Паризька угода, національна політика протидії змінам клімату, національно визначений внесок, кліматична нейтральність.

\section{Sushyk Olha. Legal character of the Paris Agreement as basis of formation of national policy for combating climate change (climate policy)}

The article obtained the legal analysis of the Paris Agreement to the United Nations Framework Convention on Climate as fundamental basis of formation climate police. It is established provisions for the respective obligations on human rights related to climate change in the court, including the rights of indigenous peoples, migrants, women's empowerment and others, which contains in the preamble the Paris Agreement.

The article emphasizing the main goal of the Paris Agreement (holding the increase in the global average temperature to well below $2{ }^{\circ} \mathrm{C}$ above pre-industrial levels) achievement by reaching global peaking of greenhouse gas emissions as soon as possible, recognizing that peaking will take longer for developing country Parties, and to undertake rapid reductions thereafter 
in accordance with the best available science, to achieve a balance between anthropogenic emissions by sources and removals by sinks of greenhouse gases in the second half of this century (climate neutrality). According to the Paris Agreement, the basis for achieving climate neutrality is multifunctional and sustainable forest management.

The article discusses the issues of nationally determined contribution (NDS) as a fundamental legal mechanism which established that the Paris Agreement that intends to achieve country Parties by reducing greenhouse gas emissions and adapt the impact of climate change in national level. More broadly, article defined the NDS procedural obligation of country Parties, requires prepare, communicate and maintain successive NDCs that it intends to achieve (every five years), which will represent a progression beyond the Party's current NDC; provide the information necessary for clarity, transparency and understanding, when communicating their NDCs; account for its NDC to promote environmental integrity; regularly provide a national greenhouse gas inventory and the information necessary to track progress in implementing and achieving its NDC. States would bring to the table the national policy of combating climate change (climate policy) certain legal measures aimed at achieving the goals contained in their NDS.

The article established that the Paris Agreement has enacted a new model of 'hybrid multilateralism' whereby emphasizing the fundamental action for combating climate change by non-state actors such as cities, business, non-governmental organization and civil society.

Key words: climate change, Paris Agreement, national policy of combating climate change, nationally determined contribution, climate neutrality.

Зміни клімату стали одним із найважливіших викликів сучасності. Світовий клімат змінився порівняно з доіндустріальним періодом. Спеціальний звіт Міжурядової групи з питань зміни клімату $(\mathrm{OOH})$ «Про вплив глобального потепління на $1,5^{\circ} \mathrm{C}$ порівняно з доіндустріальним рівнем та пов'язаними з ними глобальними сценаріями викидів парникових газів» (2019) підтверджує, що зі збільшенням середніх глобальних температур наслідки зміни клімату дають про себе знати дедалі швидше, вказуючи на те, що навіть у разі потепління до $2^{\circ} \mathrm{C}$ світ відчує драматичні наслідки зміни клімату [1].

Перші наслідки змін клімату вже зараз помітні у всьому світі: повені та посухи, пожежі та підвищення рівня моря. Країни Середземномор'я стають дедалі вразливішими до посухи та лісових пожеж, а в Північній Європі клімат стає все більш вологішим. Через підвищення рівня моря мешканці невеликих острівних держав, що розвиваються (наприклад, Мальдіви, Сейшельські Острови, Домініканська Республіка, Фіджі, Палау та ін.), змушені покидати свої домівки. Міжнародними експертами було задокументовано, що за останнє десятиліття з цієї причини близько 20-ти мільйонів людей на рік були змушені покинути своє постійне місце проживання [2].

До того ж варто підкреслити, що зміни клімату відбуваються у глобальному масштабі, більшість парникових газів нако- пичуються з часом і змішуються. Викиди від діяльності підприємств поширюються через національні кордони, а забруднення в одній державі може призвести до негативних наслідків для іншої, яка розташована за тисячі кілометрів, загрожуючи навколишньому природному середовищу у всьому світі. Тому вирішення питання запобігання змінам клімату вимагає міжнародних зусиль, у тому числі й правового характеру. Міжнародно-правові акти, що приймаються в цій сфері, стають основою для формування та реалізації національних політик щодо протидії змінам клімату різних країн.

Паризька угода в межах Рамкової конвенції ООН про зміну клімату [3] з 2020 року стала основним міжнародноправовим актом, який сьогодні визначає основні правові механізми протидії змінам клімату.

Науково-правовий аналіз цієї угоди розпочнемо відразу ж із преамбули, де наголошується, що сторони повинні брати до уваги свої зобов'язання щодо прав людини, зокрема права на здоров'я, прав корінних народів, місцевих громад, мігрантів, дітей, осіб з обмеженими можливостями, осіб, які знаходяться у вразливих обставинах, та права на розвиток, а також ґендерної рівності, розширення можливостей для жінок і справедливості між поколіннями. $\mathrm{Ha}$ підставі вищевикладених правових норм особи у випадку порушення прав, 
що пов'язані з негативними наслідками зміни клімату, мають змогу звертатись для захисту своїх прав до суду. Так, у 2020 році 9 молодих людей подали судовий позов до німецького уряду, в якому зазначали, що німецький федеральний закон Зміни клімату від 12 грудня 2019 р. порушує їхнє «право майбутніх поколінь», недостатньо сприяючи зменшенню викидів парникових газів та обмеженню зростання глобальної температури на рівні $1,5^{\circ} \mathrm{C}$ у відповідності до Паризької угоди. 29 квітня 2021 року Федеральний Конституційний Суд Німеччини визнав федеральний закон «Про зміну клімату» частково неконституційним та постановив посилити захист основних прав молоді [4]. Подібна судова справа була і в Нідерландах, де в 2019 р. за позовом Фундації Ургенда (громадська екологічна організація) Верховний Суд Нідерландів постановив, що уряд країни має забезпечити скорочення викидів парникових газів в атмосферу у 2020 році щонайменше на 25\% у порівнянні з 1990 р. [5].

Головною метою Паризької угоди (далі - ПУ) є стримування зростання глобальної середньої температури значно нижче $2{ }^{\circ} \mathrm{C}$ понад доіндустріального рівня і докладання зусиль з метою обмеження зростання температури до $1,5^{\circ} \mathrm{C}$ понад доіндустріального рівня, визнаючи, що це суттєво знизить ризики та наслідки зміни клімату (літ. а, ч. 1 ст. 2).

Окрім цього, метою ПУ $є$ підвищення здатності адаптуватися до несприятливих наслідків зміни клімату, а також сприяння опорності до зміни клімату та низьковуглецевому розвитку таким чином, щоб не ставити під загрозу виробництво продовольства (підвищення адаптивності) і забезпечення узгодженості фінансових потоків із напрямом низьковуглецевого та опірного до зміни клімату розвитку (літ. b, с ч. 1 ст. 2). Вищенаведені цілі вказують на те, що відповідно до Пу, у випадку неможливості протидіяти змінам клімату необхідним $є$ посилення діяння щодо адаптації до таких змін клімату.

Більше того, ПУ передбачає, що для реалізації цієї головної мети, що стосується температурних показників, сторони мають: 1) якомога швидше досягти глобального піку викидів парникових газів, визнаючи, що досягнення такого піку потребує більш тривалого часу для сторін - країн, що розвиваються; 2) досягти балансу між антропогенними викидами із джерел та абсорбцією поглиначами парникових газів у другій половині цього століття (ч. 1 ст. 4). Слід зазначити, що в доктрині йдеться про «досягнення балансу викидів антропогенних парникових газів шляхом їх поглинання» через появу нового терміна «кліматична нейтральність», що вводиться саме ПУ [6, с. 178].

Паризька угода, продовжуючи застосовувати мету та принципи Рамкової конвенції ООН про зміну клімату (справедливості, сталого розвитку, спільної, але диференційованої відповідальності тощо), робить свої певні правові акценти уточнюючого характеру. Зокрема, до принципу «загальної, але диференційованої відповідальності» зроблено доповнення уточнюючого змісту «у світлі різних національних обставин» (ч. 3 преамбули, ч. 3 ст. 4). ПУ встановлює і новий принцип «екологічна цілісність», який передбачає сприяння екологічній цілісності під час обліку антропогенних викидів та абсорбції відповідно до їхніх національно визначених внесків (ч. 13 ст. 4) та під час виконання державою іiі національно визначеного внеску (ч. 1 ст. 6). До того ж у преамбулі зазначається важливість забезпечення цілісності всіх екосистем, океанів у тому числі, та захист біорозмаїття, що визнаються деякими культурами як Мати Земля.

Цей міжнародно-правовий акт відмовляється від суворого поділу на країни (який існував до 2020 р.), що безпосередньо виконують зобов'язання щодо скорочення викидів парникових газів (розвинені країни) та інші країни (країни, що розвиваються). ПУ створила універсальну систему, залишаючи лише диференціацію країн на розвинені країни (ч. 4 ст. 4; ч. 1, 3 ст. 9), країни, що розвиваються (ст. 3; ч. 1, 4 ст. 4; ч. 1, 3 ст. 9 тощо), найменш розвинені країни та малі острівні держави, що розвиваються (ч. 6 ст. 4), залишаючи при цьому дієвим принцип лідерства розвинутих країн. Однак суттєвим недоліком Пу $€$ те, що, на жаль, залишилось невизначеним питання, які саме держави відносяться до тієї чи іншої категорії країн.

Паризька угода базується на специфічному правовому механізмі - національно 
визначених внесках (далі - НВВ) країнучасниць щодо зменшення викидів парникових газів. Сторони повинні вживати національні заходи для пом'якшення зміни клімату $з$ метою досягнення цілей, які передбачені в таких внесках (ч. 2 ст. 4). Цей правовий механізм є циклічним (кожні 5 років) (4. 9 ст. 4). Кожен наступний НВВ має бути більшим за поточний та відображати її найбільш можливі амбіції (4. 3 ст. 4). Національно визначені внески реєструються в публічному реєстрі, таким чином, забезпечується прозорість або ж свого роду «публічна підзвітність», а також установлюється облік НВВ (4. 12-13 ст. 4).

Окрім норм матеріального права, Паризька угода містить і важливі процесуальні норми-зобов'язання щодо НВB. Зокрема, від кожної сторони вимагається: 1) розробити, повідомити та підтримувати HBB, який вона має намір досягти (4. 2 ст. 4); 2) у НВВ надати інформацію, необхідну для забезпечення ясності, прозорості та розуміння (ч. 8 ст. 4); 3) кожні п'ять років надавати наступний $\mathrm{HBB}$, який буде відображати ії найбільш можливі амбіції, ніж попередній (4. 3, 9 ст. 4.3); 4) в обліку антропогенних викидів країн відповідно до їхніх НВВ ураховувати екологічну цілісність (4. 13 ст. 4); 5) надавати регулярну інформацію в національній доповіді про національний кадастр антропогенних викидів із джерел та абсорбції поглиначами парникових газів (ч. 7 ст. 13).

Іншими словами, відповідно до Паризької угоди країна-учасниця кожні п'ять років подає свої національно визначені внески, де зазначає цілі щодо зменшення викидів парникових газів та пом'якшення наслідків зміни клімату. Вищенаведені цілі та основні заходи (в т. ч. і правові) для досягнення таких цілей відображаються в національних політиках щодо протидії змінам клімату (кліматичних політиках), що у свою чергу буде показувати основний напрям (вектор) розвитку національного законодавства щодо протидії змінам клімату.

Наприклад, Кабінет Міністрів України 30 липня 2021 р. схвалив уже другий (оновлений) національно визначений внесок України до Паризької угоди (НBB2) [7]. Оновлений національно визначений внесок передбачає скорочення викидів парникових газів на 65\% до 2030 року від рівня викидів 1990 року, тоді як попередній внесок передбачав зменшення викидів парникових газів на 60\% до 2030 року [8].

Серед основних заходів досягнення такого показника в наступні 10 років Міністерство екології та природних ресурсів України виділяє: 1) модернізацію енергетичних та промислових підприємств; 2) розвиток відновлюваних джерел енергії; 3) заходи енергоефективності в усіх секторах економіки від виробництва, транспортування до споживання; 4) термомодернізацію будівель; 5) збільшення частки органічного сільського господарства та ресурсозберігаючих практик сільського господарства; 6) електрифікацію та оновлення транспорту; 7) запровадження ієрархії управління відходами; 8) збільшення лісистості та реформу управління лісовим фондом [9]. Виходячи з вищевикладеного, в найближчі роки в Україні буде відбуватись реформування законодавства у сфері енергетики, транспорту, сільського господарства (у т. ч. землекористування), поводження з відходами та лісового господарства.

3 точки зору доктрини міжнародного права НВB не створює матеріально-правових зобов'язань для сторін, оскільки від держав-учасниць вимагається лише процедурне визначення, повідомлення та оновлення [10, с. 146]. Держави не мають конкретних обов'язків щодо їх виконання, однак їхні зобов'язання полягають у застосуванні національних правових заходів, спрямованих на досягнення цілей, що містяться в їхніх НВB (4. 2 ст. 4).

За своєю суттю Паризька угода містить широке коло правових інструментів, які $\epsilon$ важливими для пом'якшення та адаптації змін клімату: 1) амбітність (ст. 4); 2) запровадження ринкових механізмів (ст. 6); 3) адаптацію (ст. 7); 4) питання запобігання, обмеження та усунення шкоди та збитків (ст. 8); 5) механізми підтримки, особливо для країн, що розвиваються (ст. 9-11); 6) систему моніторингу (ст. 13-15) тощо.

Так, ст. 5 Паризької угоди показує сторонам шлях до реалізації однієї з мети Паризької угоди, а саме кліматичної нейтральності у другій половині цього століття. Відповідно до Паризької угоди, основою 
для досягнення кліматичної нейтральності $\epsilon$ багатофункціональне та стале управління лісами. Сторонам рекомендується вживати заходи для збереження та збільшення поглиначів і накопичувачів парникових газів (лісів), включаючи збільшення накопичення запасів вуглецю в лісах країн, що розвиваються, та альтернативних заходів на політичному рівні (стратегічних підходів) для інтегрованого та сталого управління лісами (ст. 5). Іншими словами, сторони ПУ повинні вжити заходів щодо підтримання та поліпшення стану лісів як поглиначів та резервуарів парникових газів.

Важливі аспекти Паризької угоди зазначені й у ст. 6. По-перше, передбачено загальні положення щодо добровільної співпраці у впровадженні НВВ задля забезпечення підвищення амбітності їхніх дій щодо пом'якшення зміни клімату та адаптації до неї, а також для сприяння сталому розвиткові та екологічній цілісності (ч. 1).

По-друге, ч. 2-3 ст. 6 передбачають можливість реалізації НВВ шляхом використання міжнародного передавання результатів пом'якшення зміни клімату. 3 точки зору охорони клімату неважливо, хто саме (яка держава) скорочує викиди газів, адже парникові гази досить швидко і ретельно змішуються в атмосфері. Це дає можливість створювати «клуби» або інші різновиди зв'язків, союзів держав. Такий зв'язок між сторонами угоди забезпечить обмін між суб'єктами, що відповідають за дотриманням вимог, у рамках правових систем двох різних держав, а не міжнародна система торгівлі викидами парникових газів, як було передбачено ст. 17 Кіотського протоколу [11, с. 54].

На саміті $\mathrm{OOH} 3$ питань клімату в 2019 році був утворений Альянс за кліматичними амбіціями [12], в якому 59 сторін Рамкової конвенції ООН про зміну клімату проголосили намір заявити про збільшення національного внеску відповідно до Паризької угоди до 2020 року, а 65 сторін, включаючи ЄC, дали зрозуміти, що він спрямований на досягнення вуглецевого нейтралітету до 2050 року.

По-третє, 4. 4-6 ст. 6 містять принципи, що в процесі міжнародних передавань допоможуть зменшити викиди парникових газів. А саме йдеться про: 1) сприяння пом'якшенню наслідків викидів парникових газів через стимулювання сталого розвитку; 2) заохочення та забезпечення участі державних і приватних суб'єктів, уповноважених Стороною, у пом'якшенні наслідків викидів парникових газів; 3) внесок у скорочення рівнів викидів у приймаючої Сторони, що буде отримувати вигоду від дій з пом'якшення зміни клімату, результатом яких $\epsilon$ скорочення викидів, що можуть також використовуватися іншою Стороною для виконання свого національно визначеного внеску; 4) досягнення загального пом'якшення глобальних викидів. Щодо управління такими міжнародними передачами передбачено, що сторони повинні заохочувати сталий розвиток і забезпечувати екологічну цілісність та прозорість, у тому числі у сфері врядування.

По-четверте, ч. 8-9 ст. 6 визнають важливість інтегрованих, цілісних і збалансованих не ринкових підходів для сприяння в реалізації їхніх національних визначених внесків. Ці підходи мають на меті: сприяння цілеспрямованості дій із пом'якшення зміни клімату та адаптації до неї; посилення участі державного та приватного секторів у реалізації національно визначених внесків та створення можливостей для координації між інструментами та відповідними організаційними структурами.

Посилаючись на одну з цілей ПУ (підвищення адаптивності), ч. 2 ст. 7 визначає, що адаптація до зміни клімату $\epsilon$ глобальним викликом, що постає перед усіма в місцевому, субнаціональному, національному, регіональному та міжнародному вимірах та $\epsilon$ ключовим компонентом і робить внесок у довгострокове глобальне реагування на зміну клімату з метою захисту людей, засобів до існування та екосистем. Ця правова норма підкреслює те, що заходи щодо протидії змінам клімату потрібно передбачати вже на місцевому рівні, розпочинаючи від дій об'єднаних територіальних громад та приватних осіб загалом. Слід також звернути увагу на те, що ПУ запровадила, таким чином, нову модель гібридного мультилатералізму, що спрямована на адміністрування, організацію, активне користування і мобілізацію діянь щодо протидії змінам клімату через недержавних суб'єктів, таких як міста, підприємства, 
інвестори, регіони, громадські організації і суспільство [13, с. 23]. Як приклад взаємодії органів публічної влади та суб'єктів недержавного сектору щодо протидії змінам клімату слід згадати платформу Fossilfritt Sverige (Fossil Free Sweden), що запустив Уряд Швеції, яка спрямована на заохочення суб'єктів недержавного сектору на навчання і/впровадження різних заходів, що можна здійснювати заради протидії змінам клімату [14].

Більше того, ч. 10 ст. 7 зазначає, що кожній стороні слід у разі необхідності подавати й періодично оновлювати повідомлення з адаптації до зміни клімату, що може включати її пріоритети, потреби щодо реалізації та підтримки, плани та дії, без створення будь-якого додаткового тягаря для сторін - країн, що розвиваються. Також у ПУ зазначається, що повідомлення про адаптацію подається та оновлюється як частина або разом з іншими звітами чи документами, включаючи національний план адаптації, національний визначений внесок або національний звіт. Усі повідомлення про адаптацію реєструються у відкритому реєстрі, який веде секретаріат (4. 12 ст. 7).

Пу регулює питання, що пов'язані із запобіганням, мінімізацією та вирішенням питань з відшкодування втрат і збитків, пов'язаних з несприятливими наслідками зміни клімату, та фінансуванням країн, що розвиваються, насамперед тих, які $\epsilon$ особливо уразливими до несприятливих наслідків зміни клімату та мають значно обмежений потенціал, таких як найменш розвинені країни та малі острівні держави, що розвиваються (у статтях 8, 9, 10).

У ст. 8 ПУ прямо посилається на Варшавський міжнародний механізм щодо втрат і збитків, пов'язаний з наслідками зміни клімату, що функціонує задля допомоги країнам впоратися 3 негативними наслідками зміни клімату на основі співробітництва і стимулювання по відношенню до втрат і збитків, пов'язаних з несприятливими наслідками зміни клімату. Сторони - розвинені країни, повинні й надалі відігравати провідну роль у мобілізації кліматичного фінансування для боротьби зі зміною клімату з широкого кола джерел, інструментів і каналів, відзначаючи значну роль державних коштів (ч. 3 ст. 9).
ПУ передбачає також, що розроблення та передача технологій з метою підвищення опірності до зміни клімату та скорочення викидів парникових газів має вирішальне значення для ефективного, довгострокового глобального реагування на зміну клімату та сприяння економічному зростанню і сталому розвиткові. До того ж країнам, що розвиваються, повинна надаватися підтримка, в тому числі фінансова, задля технологічних рішень з метою досягнення балансу між підтримкою пом'якшення зміни клімату і підтримкою адаптації до зміни клімату (ч. 6 ст. 10).

Відповідно до положення ч. 1-3 ст. 13 Паризької угоди встановлено нову «систему прозорості дій та підтримки, складовою частиною якої $\epsilon$ гнучкість» у межах принципу «лідерства розвинених країн» та, зокрема, допомоги найменш розвиненим країнам і малим острівним державам, що розвиваються. Метою системи прозорості дій $є$ чітке розуміння дій щодо зміни клімату (включаючи ясність та відстеження прогресу в здійсненні НВB) і заходів з адаптації (включаючи передові практики, пріоритети, потреби та прогалини) з метою отримання інформації для загального огляду ст. 14 (ч. 5 ст. 13). Ця система прозорості «буде реалізовуватися стимулюючим, ненав'язливим, безкарним способом за поваги до національного суверенітету» (4. 13 ст. 13). ПУ передбачає оцінку підтримки, що надається стороні, а також здійснення та реалізацію ії національно визначеного внеску шляхом технічного експертного огляду (ч. 11-12 ст. 13). Таким чином, процес огляду оцінює надану інформацію, надаючи підтримку сторонам, що розвиваються, для їі впровадження (ч. 14 ст. 13).

Висновок. Паризька угода $\epsilon$ класичним прикладом угоди, в якій модель зобов'язань країн-учасниць визначається «знизу вгору» (цілі, встановлені державами в односторонньому порядку, самі собi).

Відповідно до Паризької угоди всі країни-учасниці встановлюють певні цілі щодо протидії змінам клімату, що виражають у своїх національних визначених внесках. НВВ повинні подаватися кожною країною та оновлюватися кожні п'ять років. Для досягнення цілей, що передбачені у НBB, 
держави визначають свою національну політику у сфері протидії змінам клімату та в їі межах - певні заходи правового характеру. НВВ та національна політика щодо протидії змінам клімату спрямовані для досягнення цілей ПУ.

Паризька угода також наголошує на вирішальній ролі національних недержавних суб'єктів щодо протидії змінам клімату (фізичних осіб, територіальних громад, підприємств і громадянського суспільства загалом). Основна ідея Паризької угоди: не лише держава за допомогою різних заходів зобов'язується здійснювати дії щодо протидії змінам клімату (відображені в національній політиці), а й індивідуальні суб'єкти (приватні особи) з недержавного сектору можуть впливати як на зменшення викидів парникових газів, так і пом'якшення наслідків протидії змінам клімату.

\section{ЛITEPATУРА:}

1. Спеціальний звіт Міжурядової групи з питань зміни клімату (OOH) «Про вплив глобального потепління на $1,5^{\circ} \mathrm{C}$ порівняно з до індустріальним рівнем та пов'язаними з ними глобальними сценаріями викидів парникових газів» (2019) / База даних «Міжурядова група з питань зміни клімату (OOH)». URL: https://report.ipcc.ch/sr15/pdf/sr15_spm_final.pdf (дата звернення: 04.08.2021).

2. Звіт міжнародної громадської екологічної організації Oxfam (2019) / База даних «Oxfam international». URL: https://www.oxfam.org/en/research/forced-home-climate-fuelleddisplacement (дата звернення: 04.08.2021).

3. Паризька угода / База даних «Законодавство України». URL: https://zakon.rada.gov.ua/ laws/show/995_161\#Text (дата звернення: 04.08.2021).

4. Рішення Федерального Конституційного Суду Німеччини від 24 березня 2021 р. (1 BvR 2656/18, 1 BvR 288/20, 1 BvR 96/20, 1 BvR 78/20) / База даних «Федеральний Конституційний Суд Німеччини». URL: https://www.bundesverfassungsgericht.de/SharedDocs/ Entscheidungen/EN/2021/03/rs20210324_1bvr265618en.html (дата звернення: 04.08.2021).

5. Рішення Вищого Суду Королівства Нідерландів від 20.12. 2019 p. The State of the Netherlands OF (Ministry of Economic Affairs and Climate Policy) and Stitching URGENDA / База даних «Вищий Суд Королівства Нідерландів». URL: https://www.urgenda.nl/wp-content/ uploads/ENG-Dutch-Supreme-Court-Urgenda-v-Netherlands-20-12-2019.pdf (дата звернення: 04.08.2021).

6. Ciechanowicz-McLean J., Prawo ochrony klimatu, Warszawa, 2016. 277 s.

7. Про схвалення Оновленого національно визначеного внеску України до Паризької угоди : розпорядження Кабінету Міністрів України від 30 липня 2021 р. № 868-р / База даних «Законодавство України». URL: https://zakon.rada.gov.ua/laws/show/868-2021\%D1\%80\#Text (дата звернення: 04.08.2021).

8. Про схвалення Очікуваного національно визначеного внеску України до проекту нової глобальної кліматичної угоди: розпорядження від 16.09.2015 р. № 980-р / База даних «Законодавство України». URL: https://zakon.rada.gov.ua/laws/show/980-2015-\%D1\%80\#Text (дата звернення: 04.08.2021).

9. Уряд схвалив цілі кліматичної політики України до 2030 року / База даних «Офіційний сайт Міністерства захисту довкілля та природних ресурсів України». URL: https://mepr.gov.ua/ news/37842.html (дата звернення: 04.08.2021).

10. Bodansky D. The Legal Character of the Paris Agreement, RECIEL, 25(2), 2016, p. 142-150.

11. Stavins R.N., Market Mechanisms in the Paris Climate Agreement: International Linkage under Article 6.2 In book: Stavins, Robert N., and Robert C. Stowe, eds. "The Paris Agreement and Beyond: International Climate Change Policy Post-2020". Cambridge, Mass.: Harvard Project on Climate Agreements, October 2016, 122 p.

12. На саміті ООН з питань клімату в 2019 році був утворений Альянс за кліматичними амбіціями База даних «Європейський парламент». URL: https://www.europarl.europa.eu/ doceo/document/TA-9-2019-0079_EN.html (дата звернення: 04.08.2021).

13. Nasiritousi N., Bäckstrand K. International Climate Politics in the post Paris era in: Climate Policies in the Nordics, Nordic Economic Policy Review, 2019, p. 21-50. 